Men, health and public policies: gender equality in question

\author{
Homens, saúde e políticas públicas: \\ a equidade de gênero em questão
}

M arcia Thereza Couto ${ }^{1}$

Romeu Gomes ${ }^{2}$

Abstract Thescope of this article is to pose ques-
tions on the theme of M en, Health and Public
Policiesto render debate on thesubject viable, based
on theoretical and empirical references related to
these issues. Initially, some historical landmarks
on the theme are presented to provide guidelines
for debate. An overview of the gender agenda in
public policies is then presented to introduce the
discussion about the inclusi on of a gender per-
spective in healthcare policies. After this discus-
sion, queries are raised about whether or not pol-
icies geared to men'shealth promotegender equal-
ity. In theclosingremarks, the complexity involved
in the development, implementation and evalua-
tion of health policies aimed at gender equality is
highlighted. The need for the Brazilian policy
geared towards men's health to be implemented
with other policies such that the gender matrix is
transversal in the healthcare field is also stressed.
Key words Public policies, M en, Health, Gender

Resumo 0 artigo tem por objetivo estabelecer questões acerca do tema H omens, Saúde e Políticas Públicas para a viabilização do debate sobre o assunto, com base em referências teóricas e empíricas relacionadas a essas questões. I nicialmente, alguns marcos históricos de temática são apresentados para que melhor se situe 0 debate. Em seguida, apresenta-sepanorama da agenda degênero nas políticas públicas para se introduzir a discussão acerca da inserção dessa perspectiva no âmbito das políticas de saúde. A pós essa discussão, aborda-se o questionamento sobre 0 fato de as políticas desaúde dos homens promoverem ou não a equidade de gênero. N as considerações finais, aponta-se para a complexidade queenvolvea elaboração, a implementação ea avaliação das políticas de saúde que visam à equidade de gênero, bem como se destaca a necessidade de a política brasileira voltada para a saúde dos homens articular-se com outras políticas para que a matriz de gênero seja transversal no campo da saúde. Palavras-chave Políticas públicas, H omens, Saúde, Gênero
${ }^{1}$ Universidade de São Paulo. Av. Dr. Arnaldo 455/ 2177, Cerqueira César. 01246-903 São Paulo SP. marthet@usp.br

${ }^{2}$ Instituto Fernandes

Figueira, Fiocruz. 


\section{Starting the Debate}

The purpose of this paper is to establish issues on the topic M en, $\mathrm{H}$ ealth, and Public Policies, to make the debate on the subject feasible.

The topic, historically, at certain times, distanced itself from gender studies that focused on theinequalities of women in relation to men, and in other times, helped to relativize some reductions of these studies to females.

Over 40 years ago, the first studies focused mainly on health deficits of male segments appeared in the United States. At this time, it was important to deal with a paradox as while men held more power than women did, they had disadvantages compared to such women in terms of mortality and morbidity rates ${ }^{1,2}$.

This paradox, among other ideas, and starting in the early nineties - stimulated the focus on men not only as male bodies in health studies, but also in considering them in their peculiarities as social subjects in the health-disease process, based on a relational perspective of gender ${ }^{3,4}$.

In the knowledge production area on thesubject, among other studies, a comprehensive re view developed by $\mathrm{M}$ ckinlay ${ }^{5}$ deserves special attention. It established five explanatory hypothe ses for the differences between men and women concerning mortality and morbidity, such as biological-genetic characteristics of the sexes; social differences and inequalities; different social expectations for both sexes; search for and use of health services by men, health care professionals directed to men.

Another review ${ }^{6}$ - conducted in the public health area in Brazil - found that more men die than women for the main death causes; that certain models of masculinity can bring harm to men's health; that men are the main players on violenceagainst women, children, other men and against themselves; and that unemployment compromises men's welfare and can relate to youth's suicides.

In national literature, the launch of an important issue on men's health in 2005 was an important milestone in the public health area, published by the magazine Ciência \& Saúde Coletiva from the Brazilian Association of Graduate Studies in Public Health. This issue was the first one of that year, discussing several dimensions on the topic, such as social segments, ethnic-racial issues, institutional spheres, cultural models, among others, as it included - in an interdisciplinary way - the approaches of social sciences, of epidemiology, and of biomedicine.
Currently, men's health is already included in the field of health production with a significant number of papers. In a survey conducted in the Virtual $\mathrm{H}$ ealth Library (VHL), on 04.25.2012, typing 'men's health' in the'subject' field, 1113 articles werelocated. However, concerning thetheme 'policies for men 's health', the production is much lower, indicating that it is a subject that is still under development. In thesame date, in theVH L, a survey with thewords'policies,' 'men', and 'health' found 38 papers.

Such articles were not analyzed, but taking in account the titles, only two of them deal specifically with national policies aimed at men's health, representing $5.2 \%$ of production. One of these papers refers to Australia and Ireland, while the other refers to Brazil. The most addressed topic is homoerotic "homosexuality/sexuality", representing $18.4 \%$ of production, followed by the topics "specific diseases" (10.5\%), "gender" (10.5\%), "reproductive health" (10.5\%), "masculinity and health" (7.8\%), "fascism" (5.2\%), and "prostitution" (5.2\%). The remaining papers $(26.3 \%)$ addressed several topics, each with a simple frequency of 1 article.

Currently, one of the major challenges for public health is to bring the main principles established by the vast national and international production on the relationship men $\mathrm{x}$ health for the policy area, without losing the relational perspective of gender, in which dealing with men's health necessarily involves dealing with women's, and vice versa. From this perspective, the peculiarities of both genders should not be disregarded, and should not be excluded from each other. This challenge is the motto of our debate.

\section{The gender agenda in public policies}

According to Castro $^{7}$, taking into account the dialectic between human rights in general and human rights of many ones concerning their vulnerabilities and their possibilities, the discussion of gender public policies is placed in the most comprehensive framework of the pro human rights movement, of citizenship and of affirmative action policies, and by identities, based on the recognition that, beyond the economy, there are several systems of discrimination and exploiting asking for State intervention.

It also recognizes that the establishment of a gender agenda in public policies reflects the development of research on the women condition in public and privatespaces, and of development of the gender analytical category, a fact that stands 
out nationally and internationally since $1980^{8-10}$. Recently, studies on men and masculinities bring new contributions to the debate, as well as the need to further the discussion of how to involve men to achieve gender equality ${ }^{4,11,12}$.

In the complexity involving public policies understood here as courses of State action, guided by certain goals, reflecting or representing a set of interests ${ }^{9}$ - it is also important to consider the existence of multiple elements in action, such as intentionality, instrumentality, interaction, power, and temporality. Thus, the definitions of problems, targets of State action, evolvethrough successive waves of decision making, once different players (part of groups, organizations, institutions, and also of international organizations) are embedded in the processes of definition, implementation, and monitoring of the policies, which are usually multifaceted, disputed, and negotiated ${ }^{10,13}$.

In Brazil, public policies on gender were fomented in the late seventies in the broader context of redemocratization of the State and of the fight to improve the quality of life and work. In this scenario, women's movement and participation in social movements and political parties boosted up the discussion on the asymmetry of power between men and women in public and private spaces. Undoubtedly, women's history in these movements reflects the history of their formation as collective subject and with representation in citizenship, bringing up issues and topics so far limited to the private sector. Although it deviates from the purposes and scope of this discussion, it is important to note that in the relationship between State and social movements (especially the feminist movement), the debate on the preservation of autonomy and/or integration of social movements in the formulation, implementation, and control of public policies has been always present, as well as on the risk of emptying the dimension of power that the gender category brings by public policies,10,14 and sometimes, in scientific research ${ }^{15}$.

The gender agenda in public policies can be understood as a synthesis agenda of topics prioritized by several players, having as the core the socio-historical relations between men and women producing inequalities. The first initiatives in Brazil to include such referential in public policies took place in the eighties, especially in the areas of justice ( with the creation of the National Council of Women's Rights in 1985, an agency of the Ministry of Justice, and of the First Police Station for Women's D efense in the state of São
Paulo, in the same year) and of healthcare (creation of the Program for Integral Assistance to Women's Health-PAISM in 1984). Currently, the gender agenda in the country has been directed to violence, healthcare, employment and income generation, education, jobs, urban infrastructure and housing, the agrarian issue, access to political power, among many other topics ${ }^{9}$.

First, the gender public policies were those that recognized theimportance of social inequalities for women compared to men, they sought to minimize and/or overcome these inequalities and had women as the beneficiaries. There are, recently, evidences of the institutionalization of gender in public policies, especially in healthcare and education ${ }^{16}$, result of multifaceted processes triggered by and from the feminist movement and women's movements. There is also the interaction between plural theoretical and political movements originated from political performances from different social groups denouncing inequality and invisibility to the State (women, gays, transsexuals), forming a process in constant struggle and internal negotiation to social movements and groups and in their relationship with political parties and with the State.

Concerning interaction between political and theoretical movements, the dilemmas in the construction of equality between men and women resulted in a debate about the identification of the theoretical construction that underlies the formulation of public policies, with academic and political repercussions. According to this basis, public policies would serveto benefit women and would represent a historical reckoning in several areas in which they were subjected to - an approach that takes gender into its constitutive and explanatory dimensions of relationships between men and women. Therefore, gender becomes to be perceived not as a socio-historical condition only that determines, by itself, differentials of vulnerability and reproduces inequalities between men and women, but as a relational (not to be confused with supplementary, but that establishes and reproduces power asymmetries) and transversal category (hence its interaction with race/ ethnicity, social class, differences of generation, cultural capital, etc. $)^{14,16}$.

In the current debate on gender in public policies, the dimension of the transversality and the perspective of equality has deserved national and international attention $n^{8,9,12,14}$. Concerning transversality, once the gender is conceived as constituent and constitutive of representations about maleand female, and widely disseminated as how 
people, groups, and institutions stand and intervene in the world, it is not possible to think the existence of neutral public policies in terms of gender. As a result, it is strongly recommended that any definition of political action considers the different impacts according to gender. In concrete terms, however, transversality has been implemented through a claim that theissue of women istaken into consideration whenever programs and policies are formulated and implemented. The discussion of equality, in turn, leads to the questioning of the difference expressed in inequality and of the respective solution as equal value and opportunities, considering the differences and particularities of groups and individuals. Given that gender - as an element that defines, organizes, and targets social practices - produces inequality, the public policies, inserted in rights and equality, should address these inequalities by changing the milestones that underpin and legitimize them, seeking to involve men and women in the debate and struggle for rights and citizenship. According to Giffin ${ }^{14}$, gender equality does not refer to any difference, but to the differences that are considered unfair, the identification of inequalities is based on values that turn men and women unequal in terms of social importance. Thus, it is about to deal with differences that, as distinctions of individuals, are worth the same as ethical subject and of rights for the society.

Public policies in health and gender perspective

According to Vilella et al. ${ }^{17}$, theincorporation of the gender category in the health area - if politically committed - can bring new dimensions to better understand life events of women and men in the search for expansion of autonomy.

The political-academic process to establish and develop a gender perspectivein public health policies took shapein thehistorical, political, and cultural context of the country's democratization, and of the entire health system reorganization. According to Aquino ${ }^{18}$, beyond the direct influence of feminism in the academy and in government departments, agencies such as the World Health Organization (WHO) and Pan American Health Organization ( $\mathrm{PAHO}$ ) have promoted the institutionalization of a gender perspective in research and public health policies. However, it warns that its widespread use has often emptied theheuristic power of the concept, by reducing it to the description of the differences between men and women into mere substitution to sex.
PAISM is an example of how the women's movement, in politics and academics, introduces the gender dimension in public heal th policies. It is not only because women (feminists) begin to compose the group of elaborators of the Brazilian Ministry of $\mathrm{Health}$ (MS) program, but for the practical-political principles that guided the program, the displacement of reproductive issues of the moral sphere and of the restricted role of the State to the field of individual ethical decision and of the social right ${ }^{19}$. Moreover, in healthcare, the integrality, in which addresses women's health in its overall dimension and in all stages of its life cycle, and the universality ${ }^{20}$.

From the nineties, in close collaboration with gay and lesbian movements, the women's movement adds other gender issues, demands, and perspectives to think about reproductive rights and sexual rights as an expression of citizenship ${ }^{21}$. After almost 30 years from its creation, the analysis on the implementation of PAISM demonstrated that, despitesomeislands of excellence, the program was not implemented satisfactorily in the national territory. Among the factors involved in this evaluation, the context of crisis and tax adjustment in the nineties and the reform agenda of the State, which resulted in targeted policies, deserves attention, reflecting the fragmentation of programs by injury or condition, which are successively created, especially in the areas of prenatal care, delivery and contraception assistance, but not providing political and financial basesfor support and continuity. M oreover, there is the delay, thegap between the proposals, planning and practical measures, and lack of political commitment to implement the program ${ }^{9,22,23}$.

In 2004, the Brazilian M inistry of $\mathrm{H}$ ealth (MS) launched the National Policy for I ntegral Attention to Women's Health (PNAISM). This policy, besides resuming PAISM principalsand reaffirming women's health as priority ${ }^{24}$, considers, among other things, the specificities of black, Indian, lesbians and sex workers women, supported by a clear gender focus that has integrality and health promotion as guiding principles. Moreover, it expresses the search for consolidation of progress in sexual and reproductive rights, strengthening the fight against domestic and sexual violence and adds the prevention and treatment of women living with HIV/Aids, and women suffering from chronic diseases and gynecological cancer.

PAISM, and even its update in PNAISM, had little impact on the inclusion of men, even considering one of its priority areas, which is family 
planning. Thus, we question, following the arguments by Medrado and Lyra ${ }^{11}$ on what conceptions of men guidegender policies in thehealth field; and what isthegoal of including men in the health gender agenda? In other words, men as individuals involved in the historical, social, cultural, and linguistic process of gender, become participantsin theproduction, maintenanceand/ or redefinition of power relations with women (and other men). Therefore, the challenge faced is to include them so that they will know and have answers about their needs and vulnerabilities and, through this previous measure, they will work out their relationships with women, concerning health care, to perform more symmetrical relations as individuals with thesamevalue in a communicative relationship.

Recent review made by Siliquini et al. ${ }^{8}$ and Baker and Aguayo ${ }^{25}$ on the inclusion of gender perspectives and masculinities in public health policies, at national and international levels, suggest answers to questions made by M edrado and Lyra $^{11}$. They point out that, although the gender analytical system found in many programs and action plans refers to the notion of gender as a dynamic and fluid construction that works interconnected in the social plan with other references (class, age, race/ethnicity, sexuality), producing different results (and sometimes contradictory ones) for men and women, the policies still keep a strong emphasis on women as beneficiaries, and men are still not seen as potential subjects for a study which goal is to achieve gender equality. This is a simplistic way of addressing the policy by treating only part of the power issue, noting that the benefits given to women as a correction for inequality can sometimes, as a biopolitical disciplinary device, increasenormalization on women, which should arguefor women and men. Another issue to be further developed is the diversity of value that actually operates within the male population, turning power into a complex issue.

Thus, although gender constitutes a reference in health policies in different countries, for at least three decades, one wonders exactly what defines gender equality in the context of both men and women. For Barker and Aguayo ${ }^{25}$, men, only recently, have been considered as relevant players of policies and programs. This statement seems to be valid both for assistance programs aimed at recovery of health damages (sickness), and aimed at health promotion and prevention practices, according to PAISM or PNAISM. Accordingly, theinclusion of men, as constituent players of the gender inequality issue and also players allied to reduce inequalities between men and women, has recently been considered.

It is worth pointing out, unlike other countries, Brazil has a weak expression of men's organized social movements guided by discussions and demands according to the referential of gender or masculinity. Another factor may be due to the difficulty, by scholars and policy makers, in promoting a 'man-generic' ${ }^{26}$ review. Once that originally the gender incorporation in public policies is due to feminism, which fights the asymmetry and inequality between men and women. M en tends to be taken as an 'other' nearly homogeneous, who tries to preserve the power and privileges that their sex condition allows. Treated as 'equals', men are(in) visible concerning the contradictions and vulnerabilities they face concerning the concrete exercise of masculinity. Is it possible, therefore, coming from the recognition of these different realities crossed by theinteraction among social norms, symbols, and experience of concrete individuals, to advance in the understanding of the meaning of gender equality and in the formulation and implementation of proposals to consider the plurality of forms of existing and of relating men and women ${ }^{12,25}$.

Various analyses suggest that the incorporation of a positive and activework with men within gender equality policies (health and other areas such as education and violence) has been supported by many initiatives and documents from United Nations and from WH 8,25,27.

The recognition that the implementation of gender equality policies in healthcare is a legitimate and appropriate way concerns, at first, to identify similarities and differences in needs of men and women 's health (both considered in the plural); then, to ensure equal opportunities for men and women to access resources so that they can achieve their potentials for health. However, this does not mean ignoring the social dimension of asymmetries and inequalities between men and women, or that many men rely on and benefit from the existing gender prerogatives of gender reinforced by institutions such as family, church, State. Likewise, Barker and Aguayo ${ }^{25}$ and M edrado et al. ${ }^{28}$ reinforce that the gender agenda focusing on men should aim for gender equity in favor of women, girls, and of men and boys themselves. And the programs aimed at men should be careful to not have negative impacts on women.

Despitethis recognition, the visibleexistence of gender equality in projects and programs that includemen is still unclear. Recent studies held in 
Brazil, Mexico and Chile ${ }^{25}$, and Ireland and Australi ${ }^{29}$ show that most projects have poor range, are of short term and are not incorporated into the government agenda of public policies. Another weak element of the programs is thelack of records about the effects, outcomes, and impacts concerning gender equality.

Among the three target countries of Barker and Aguayo's studies ${ }^{25}$, only Brazil has a public health policy based on a gender perspective and focused on males: the Brazilian National M en's Health Policy (PNAISH), officially launched in $2009^{30}$. The analysis by Richardson and Smith ${ }^{29}$ and Richardson and Carroll ${ }^{31}$ highlights I reland's policy, dating from 2008 ("National men's health policy 2008-2013: working with men in Ireland to achieve optimum health and wellbeing") and Australian policy, established in 2010 ("National male health policy: building on the strengths of Australian males").

Men's health policy:

the search for gender equality in health?

Once men 's health care policies are recent, there are not many studies on the constitution process and, even more restricted, about its implementation. For the Brazilian policy, the studies conducted by Carrara et al. ${ }^{32}$ and $M$ edrado et al. ${ }^{28,33}$ stand out, as well as therecent assessment survey conducted in fiveBrazilian states on the first year of implementation of PN AISH ${ }^{34}$, which main re sults are presented in papers about this topic.

One of the first aspects that stands out is that thejustification for the policy-making process of the three countries is related to the development of a gender and health research subarea, which focuses on the social construction of masculinity and its impact on the process of health, illness, and care.

A second feature common to the three policies is the emphasis on the socio-cultural barriers related to men's health care $e^{29,31,32}$. The institutional barriers to access health care stand out as well, especially in the case of Brazil, mostly in primary care $\mathrm{1}^{13,32}$, once men prefer to seek ambulatory and hospital care.

Therefore, thegender perspective is perceived as explanatory matrix of determinants of men's health-illness process and care, and three policies aim at health promotion, prevention, and recovery in terms of individuals and collective. The questioning is then: the recognition of historical and socio-cultural dimensions of masculinity and their influence on men's health, illness and care would be enough to characterize the policies re lated to gender equality? Power and relational dimensions among men, and between men and women, would be covered?

Taking into account the three countries and focusing on the Brazilian case, it is understood that its institutionalization promotes changes and innovations in different levels - which influence each other - that need to be addressed in the context of the gender perspective adopted here: 1 . creates a view of men as a specific population group, 2. reinforces and legitimizes men's health as priority State action; 3. establishes theneed for planning and action by the different levels of healthcare management.

Concerning the first aspect, in reestablishing a vision of men as a specific population group, there is a risk of reproducing the tendency to focus the gender as one, essentializing masculinity in a single reference of man. Such risk of gender relational dimension suppression was considered an important challengein theimplementation of

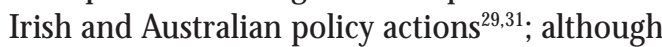
policy documents show recognition and concern in considering and including men in terms of ethnic diversity, class status, sexual orientation, among others. In the case of PNAISH, although one of the specific goals include to [...] promote comprehensive health care for all men including indigenous, black, quilombola, gays, bisexuals, transsexuals, rural workers, with disabilities, at risk, in prison, among others, developing strategies for promoting equality for different social group $\mathrm{s}^{30}$, in theN ational Policy Action Plan 2009-2011 there is no reference to the diversity mentioned above among the priority actions for the period ${ }^{35}$. Thus, the recognition of the plurality of masculinities ways and men's existing conditions seem to contradict with the statement than men (here taken as a whole) are 'vulnerable' to diseases as they find it "difficult to recognizetheir needs, perpetuating the magical thinking that rejects the possibility of falling ill" ${ }^{30}$. Although the first actions to implement the policies in the three countries are in progress, there is, in Brazil, a gap between a theoretical proposition that recognizes the diversity and an institutional action that reinforces theuniqueness.

Thesecond aspect - to postulatemen's health as priority - refers mainly to the discussion on the current use (and abuse) of demographic and epidemiological data as argumentative resources to justify the need for policy-making. PNAISH's document brings the rhetorical use of morbidity 
and mortality information that help to create a victimizing reading of men, and besides, forging a subject (man) who needs special attention or privileges ${ }^{28,32}$. Secondly, we must pay attention to the fact that the use of morbidity and mortality data by policy-makers take part in the long historical process of medicalization of the malebody. Bringing out the full health of men as a target of government action involves rethinking what is specific in men'shealth needs (compared to women's) and how these are established from a power game in which groups from civil society, academics, medical bodies, and government make part. M oreover, definitions of 'new' men's health needs and respectiverisk of medicalization of malebodies, respond to a complex articulation of economic, cultural, technological and political process$\mathrm{es}^{32}$. Thirdly, it is also important to take into account therisk concerning reinforcement of men's accountability concerning health, as well as a heal th management entirely centered on theindividual (and on disease).

Although literature on men $x$ care relationship tends to emphasize men's lack of concern for their health (reference to femalemediation to men's health care is a clear example of this), the transposition of the cultural dimension of care for assistance and work of professionals should be performed from a perspective that considers the cultural dimension, but that do not reinforce it, once the belief is based on the development of autonomy of individuals concerning health care. Related to this, the focus on individual responsibility to reduce the risk of getting sick cannot ignore structural factors, such as socio-economic conditions, the reference to race/ethnicity and to sexual orientation that, as reported in literature $\mathrm{t}^{3,5,6}$, have profound impact on health.

Regarding the latter, the recent policy concerning men implemented in the country (aswell as in Australia and Ireland) may become an important resource for managers and professionals who wanted to further advancein men'shealth (and, relationally, women's health), from the perspectivethat healthcare is a right. However, there are important challenges for its effective implementation, especially in primary care, which was perceived as PNAISH 's priority action ${ }^{30}$. Among them: 1. To recognize which men's heal th demands and needs are actually under primary care, and search for related answers that rely on fully care and that do not becomeanother emergency room or specialist appointment, 2. to ensure enough State resources to implement action plans on the policy in a consistent manner, as well to assess resultsachieved; 3 . invest in the training of healthcare managers and professionals so they can recognize that men 's health needs are produced under a practical-symbolic production environment focused on gender, race, class, generation, among other identity references 28,$34 ; 4$. To reinforce the need for social involvement in the definition, implementation, and evaluation process of policy actions, acknowledging that the discussion among different social groups builds and establishes the social control of public policies ${ }^{28} ; 5$. To enhance, from existing and of priority healthcare networks of the M inistry of $\mathrm{H}$ ealth (for example, women's health, occupational health, GLBT health, program to fight violence, among others), aspects related to men's health from a relational and transversal gender perspective ${ }^{34}$.

\section{Final considerations}

The challenge of gender equality in public policies have been the subject of national and international debate ${ }^{8,12,14}$. In Brazil, the creation of men's healthcare took place in $2009^{30}$ and, unlike women's health policies (PAISM and PNAISM), which are result of a historical role of feminists and gay and lesbian groups, was developed from a governmental political decision at government level|27,31.

Such discussion points to the acknowledgment on the complexity involved in the development, implementation, and evaluation of health policies towards gender equality. PNAISH principles and goals should be discussed and supported not only as a policy aimed at men, but as cross-gender policy in the context of healthcare actions. Thus, it is important to resume the discussion on gender transversality and equality, once that more than having women (and men) included in separate policies as beneficiaries, it is necessary to legitimize gender perspectives in universal policies?

PNAISH 's first studies ${ }^{28,32-34}$ point out that a conception of a transversal and equitable gender is not quite out there. Therefore, its asks for further theorical-political investment, and a more reflective reading based on research and discussions that are becoming more visible in public health in the last years years. PNAISH does not represent, in political terms, thestruggle of social movements for identity, once the history on its creation does not come from a struggle for affirmative actions based on pro-human rights and of citizenship. However, it is through the dynamics and engendering that this policy can and 
should establish with others (PNAISM, N ational Health Policy of Black Population ${ }^{36}$, Brazil Without Homophobia Programme ${ }^{37}$, among others) that can move towards a matrix of transversal gender for health. In other words, therelationship among these policies, from principles and guidelines towards gender, will be able to produce changes in the constructs that (re)produce healthcare inequalities in men and women. 


\section{Collaborations}

M T Couto and R Gomes participated equally in all stages of preparation of the article.

\section{References}

1. Courtenay WH, Keeling RP. Men, Gender, and Health: Toward an Interdisciplinary Approach. J Am Coll Health 2000; 48(6):243-246.

2. Gomes R. Apresentação. In: Gomes R, organizador. A Saúde do Homem em Debate. Rio de Janeiro: Fiocruz; 2011. p. 11-18.

3. Courtenay WH. Constructions of Masculinity and their Influence on Men's well-being: a theory of gender and health. Soc Sci Med 2000; 50(10):13851401.

4. Schraiber LB, Gomes R, Couto MT. Homens na pauta da saúde coletiva. Cien Saude Colet 2005; 10(1): 7-17.

5. M ckinlay E. M en and $\mathrm{H}$ ealth: a literature review. Wellington: Wellington School of Medicine and H ealth Sciences, Otago University; 2005.

6. Gomes R, Nascimento EF. Produção do conhecimento sobre a relação homem-saúde. Cad Saude Publica 2006; 22(5):901-991.

7. Castro M G. Políticas públicas por identidades e de ações afirmativas. Acessando gênero e raça, na classe, focalizando juventudes. 2006. [página na Internet]. [acessado 2012 jun 10]. Disponível em: http:/ /www.egov.ufsc.br/portal/sites/default/files/anexos/ 28334-28345-1-PB.pdf.

8. Siliquini $R$, Chiado Piat $S$, Versino $E$, Gianino $M M$, Mutu D, Cossutta M, Manzoli L. Gender health and policies: the estate of the art from exposure to solutions. J Prev M ed Hyg 2009; 50(1):58-75.

9. Farah MFS. Gênero e Políticas públicas. Rev Estudos feministas 2004; 12(1):47-71.

10. Stromquist NP. Políticas públicas de Estado e equidade de gênero. Rev. Bras. Educ. 1996; 1(jan-abr):2749.

11. Medrado B, Lyra J. Por uma matriz feminista de gênero para os estudos sobre homens e masculinidades. Rev Estudos Feministas 2008; 16(3):809-840.

12. Doyal L. Gender equity in health: debates and dilemmas. Soc Sci M ed 2000; 51(6):931-939.

13. Ferraz D, Kraiczyk J. Gênero e políticas públicas de saúde - construindo respostas para o enfrentamento das desigualdades no âmbito do SUS. Revista de Psicologia da UNESP 2010; 9(1):70-82.

14. Giffin K. Pobreza, desigualdade e eqüidade em saúde: considerações a partir de uma perspectiva de gênero transversal. Cad Saude Publica 2002; 18 (Supl.): 103-112.

15. Araújo $M F$, Schraiber LB, Cohen DD. Penetração da perspectiva de gênero e análise crítica do desenvolvimento do conceito na produção científica da Saúde Coletiva. Interface Comun Saúde Educ 2011; 15(38):805-818.

16. M eyer DE. Teorias e políticas de gênero: fragmentos históricos e desafios atuais. Rev Bras Enferm 2004; 57(1):13-18.

17. Vilella W, M onteiro S, Vargas E. A incorporação de novos temas e saberes nos estudos em saúde coletiva: o caso do uso da categoria gênero. Cien Saude Colet 2009; 14(4):997-1006.

18. Aquino EM. Gênero e saúde: perfil e tendências da produção científica no Brasil. Rev Saude Publica 2006; 40(№ Esp.) :121-132. 
19. Correa S. PAISM : uma história sem fim. Rev. Bras. Estudos Pop. 1993; 10(1-2):3-11.

20. Costa AM, Aquino E. Saúde da mulher na reforma sanitária brasileira. In: Costa AM, M erchan-Hamann $E$, Tajer $D$, organizadores. Saúde, equidade e gênero. Brasília: UNB, Abrasco-Alames; 2000. p. 181-202.

21. Ávila B. Direitos sexuais e reprodutivos: desafios para as políticas de saúde. Cad Saude Publica 2003; 19(Supl. 2):465-469.

22. Costa AM. Desenvolvimento e implantação do PAISM no Brasil: revisitando percursos. In: Galvão L, Díaz J, organizadores. Saúde sexual e reprodutiva no Brasil. São Paulo: Hucitec; 1999. p. 70-103.

23. Costa AM. Participação social na conquista das políticas de saúde para mulheres no Brasil. Cien Saude Colet 2009; 14(4):1073-1083.

24. Brasil. M inistério da Saúde (M S). Secretaria de Atenção à Saúde. Departamento de Ações Programáticas Estratégicas. Política Nacional de Atenção Inte gral à Saúde da Mulher. Princípios e Diretrizes. Brasília: M S; 2004. (Série C. Projetos, Programas e Relatórios).

25. Barker G, Aguayo F. Masculinidades y políticas de equidad de género: reflexiones a partir de la encuesta, imagens y una revisión de políticas en Brasil Chile y M éxico. Rio de Janeiro: Profundo; 2011.

26. Schofield T, Connell RW, Walker L, Wood JL, Butland DL. Understanding M en's Health and IIIness: A gender-relations approach to policy, research, and practice. I Am Coll Health 2000; 48(6):247-256

27. Smith JA, Robertson S, Richardson N. Understanding gender equity in the context of men's health policy development. Health Promot J Austr 2010; 21(1):76-77.

28. Medrado B, Lyra J, Azevedo M. "Eu não sou só próstata, eu sou um homem". Por uma política pública de saúde transformadora da ordem de gênero. In: Gomes R, organizador. A Saúde do Homem em Debate. Rio de Janeiro: Fiocruz; 2011. p. 39-74.

29. Richardson N, Smith JA. National men's health policies in Ireland and Australia: What are the challenges associated with transitioning from development to implementation? Public $\mathrm{H}$ ealth 2011; 125(7): 424-432.
30. Brasil. M inistério da Saúde (M S). Secretaria de Atenção à Saúde. Departamento de Ações Programáticas Estratégicas. Política nacional de atenção integral à saúde do homem: princípios e diretrizes. Brasília: Editora do Ministério da Saúde; 2009.

31. Richardson N, Carroll, PC. Getting men's health onto a policy agenda-charting the development of a National Men's Health Policy in Ireland. JM H 2009; 6(2):105-113.

32. Carrara S, Russo J, Faro L. A política de atenção à saúde do homem no Brasil: os paradoxos da medicalização do corpo masculino. Physis 2009; 19(3): 659-678.

33. Medrado B, Lyra J, Valente M, Azevedo M, Noca J. A construção de uma política nacional de atenção integral à saúde do homem. In: Trindade ZA, Menandro MCS, N ascimento CRR, organizadores. M asculinidades e práticas de Saúde. Vitória: GM Editora; 2011. p. 27-35.

34. Gomes R, Leal AF, Couto MT, Knauth D, Lima AM M oura EC, Silva GSN, Figueiredo WS, Urdaneta M. Avaliação das ações iniciais da implantação da política nacional de atenção integral à saúde do homem. Rio de Janeiro: IFF; 2012.

35. Brasil. M inistério da Saúde. Secretaria de Atenção à Saúde. Departamento de Ações Programáticas e Estratégicas. Plano de ação nacional 2009-2011 da PNAISH. Brasília: MS: 2009.

36. Brasil. M inistério da Saúde (MS). Secretaria de Gestão Estratégica e Participativa. Política Nacional de Saúde Integral da população N egra. Brasília: Ed. do Ministério da Saúde; 2010.

37. Brasil. Ministério da Saúde (MS). Conselho Nacional de Combate à Discriminação. Brasil sem homofobia: programa de combate à violência e à discriminação contra GLTB e promoção da cidadania homossexual. Brasília: Ministério da Saúde; 2004. 